\title{
WSPÓLNOTA WARTOŚCI W UNII EUROPEJSKIEJ Z PERSPEKTYWY ART. 90 UST. 1 KONSTYTUCJI RP
}

\section{ART. 90 UST. 1 KONSTYTUCJI RP JAKO PODSTAWA PRZYSTĄPIENIA POLSKI DO UNII EUROPEJSKIEJ}

Już w trakcie prac nad projektem obowiązującej obecnie Konstytucji RP uznano, że powinny się w niej znaleźć przepisy umożliwiające przystapienie Polski do Unii Europejskiej. Słusznie zakładano, że ze względu na integracyjny („ponadnarodowy”) charakter Unii, odróżniający ją od klasycznych organizacji międzynarodowych, należy zamieścić w Konstytucji przepis oddający istotę akcesji do Unii. Tą istota jest skutek umowy akcesyjnej, polegający na przeniesieniu kompetencji organów władzy państwowej poza konstytucyjny aparat państwa. W rezultacie konstytucyjna podstawą akcesji RP do Unii Europejskiej stał się art. 90 ust. 1 Konstytucji RP, zgodnie z którym: „Rzeczpospolita Polska może na podstawie umowy międzynarodowej przekazać organizacji międzynarodowej lub organowi międzynarodowemu kompetencje organów władzy państwowej w niektórych sprawach”. W doktrynie prawa konstytucyjnego i orzecznictwie Trybunału Konstytucyjnego (TK) poddano wszechstronnej analizie zarówno treść, jak i procedurę instytucji przekazania kompetencji $\mathrm{w}$ trybie art. 90. Natomiast w przypadku tego opracowania nacisk zostanie położony na implikacje art. 90 ust. 1 Konstytucji RP w sferze aksjologicznej.

Pierwszy aspekt, na który zwracano uwagę w dyskusjach nad projektem i wczesnych komentarzach, to brak w przepisie wskazania nie tylko nazwy własnej, ale także cech organizacji bądź organu, któremu przekazuje się kompetencje. Jak wiadomo, inne rozwiązanie przyjęto w art. 23 niemieckiej Ustawy zasadniczej, w której zezwala się na uczestnictwo RFN w rozwijaniu UE pod warunkiem, że Unia będzie respektować zasady demokracji, państwa prawa, zasady socjalne, federacyjne i zasadę subsydiarności oraz że zagwarantuje ochroną praw podstawowych na poziomie porównywalnym z Ustawą zasadnicza.

Wykładnia art. 90 ust. 1 Konstytucji RP idzie w podobnym kierunku. Pomimo braku w przepisie charakterystyki podmiotów, na rzecz których następuje przekazanie kompetencji, nie jest obojętne to, co w sferze aksjologicznej reprezentuje określona organizacja lub organ międzynarodowy. Polska nie może bowiem przystapić do organizacji, której działalność byłaby sprzeczna z zasadami ustroju Rzeczypospolitej, wyrażonymi w rozdziale pierwszym Konstytucji. To one określaja kierunki i ramy prawne aktywności wewnętrznej i zewnętrznej państwa. Dlatego zgodzić się należy ze stanowiskiem doktryny, 
że daną organizację lub organ międzynarodowy musi łączyć z Rzeczpospolitą wspólny system wartości uniwersalnych, takich jak demokratyczny ustrój i przestrzeganie praw człowieka. Wyklucza to możliwość przekazania uprawnień organizacji prowadzącej działalność sprzeczną z proklamowaną w Konstytucji zasada państwa prawnego, uniwersalnymi prawami człowieka lub wiążącym Polskę prawem międzynarodowym ${ }^{1}$.

To jednak nie wszystko, pojawia się bowiem pytanie, jak Polska powinna postapić, gdyby organizacja (w tym także oczywiście UE), sprzeniewierzyła się zasadom składającym się na ów wspólny system wartości. W art. 90 Konstytucji RP nie przewiduje się wystapienia, ale większość doktryny dopuszczała taką możliwość i znajdowała po temu podstawę w art. 56 Konwencji wiedeńskiej o prawie traktatów ${ }^{2}$. Jak wiadomo, obecnie procedura wystapienia z Unii jest wyraźnie przewidziana w art. 50 Traktatu o Unii Europejskiej.

Powinno się w tej sytuacji wypełnić lukę regulacyjną w prawie krajowym. Czyni się to zwykle, korzystając z konstrukcji tzw. aktu przeciwnego (por. wyrok FTK z 12 października 1993 r. w sprawie Brunner), którego przyjęcie skutkowałoby wystapieniem z Unii (organizacji międzynarodowej) i powrotem przekazanych kompetencji do Rzeczypospolitej. Takie uzupełnienie Konstytucji wprowadzono do ustawy o umowach międzynarodowych. Zgodnie z art. 22a ust. 2 tej ustawy przedłożenie Prezydentowi RP projektu decyzji o wystąpieniu z Unii Europejskiej jest dokonywane po uzyskaniu zgody wyrażonej w ustawie ${ }^{3}$.

Rozwiązanie to nie wydaje się prawidłowe. Przede wszystkim nie istnieja racjonalne argumenty przemawiajace za tym, by akt przeciwny podejmować w innym trybie niż akt przekazujący kompetencje, który wymaga spełnienia znacznie trudniejszych niż w przypadku ustawy warunków określonych w art. 90 ust. 2 lub zgody wyrażonej w referendum ogólnonarodowym. Konsekwencje ustrojowe wystapienia z Unii są bowiem porównywalne z akcesją do niej. Zwykła większość głosów w Sejmie RP, potrzebna do uchwalenia ustawy wyrażającej zgodę na wypowiedzenie traktatów unijnych, nie może zastapić kwalifikowanej większości dwóch trzecich głosów w Sejmie i Senacie lub referendum.

Najpoważniejszy wydaje się argument materialny. Zgodnie z art. 90 ust. 2 i 3 Naród w drodze referendum lub przedstawiciele Narodu kwalifikowaną większością dwóch trzecich w każdej z izb decyduja że systemy wartości Rzeczypospolitej i Unii Europejskiej są do tego stopnia wspólne, że Polska może zostać członkiem Unii ze wszystkimi tego konsekwencjami. Czy większość zwykła, wystarczająca do uchwalenia ustawy, może wiążąco stwierdzić,

${ }^{1}$ Por. K. Działocha, Artykut 90, w: L. Garlicki (red.), Konstytucja Rzeczypospolitej Polskiej. Komentarz, t. 1, Warszawa 1999, s. 5.

${ }^{2} \mathrm{~W}$ art. 56 ust. 1 Konwencji wiedeńskiej o prawie traktatów przewidziano, że: „Traktat, który nie zawiera postanowienia dotyczącego jego wygaśnięcia i nie przewiduje wypowiedzenia ani wycofania się z niego, nie podlega wypowiedzeniu ani wycofaniu się z niego, chyba że: a) ustalono, że strony miały zamiar dopuścić możliwość wypowiedzenia lub wycofania się, bądź b) prawa do wypowiedzenia lub wycofania się można domniemywać się z charakteru traktatu”.

${ }^{3}$ Ustawa o umowach międzynarodowych z 14 kwietnia 2000 r., Dz. U. 2000, Nr 39, poz. 443 ze zm. 
że wspólnota wartości już nie istnieje, choć ani przepisy traktatów unijnych, ani konstytucja RP nie uległy zmianie? Oczywiście może się zdarzyć, że w trakcie trwania członkostwa praktyka unijna bądź państwowa odejdzie od takiego rozumienia traktatów lub Konstytucji, jakie istniało w chwili akcesji. Wówczas, mając na uwadze konstytucyjną rangę takiego aktu, tym bardziej można twierdzić, że to Narodowi przysługuje prawo podjęcia decyzji z zastrzeżeniem dochowania szczególnego, chroniącego jego suwerenność trybie z art. 90, a nie zwykłej większości parlamentarnej. Podobne rozwiązanie zaproponował w swoich konkluzjach w 2010 r. zespół naukowy powołany przez Marszałka Sejmu ${ }^{4}$.

\section{CHARAKTER ZOBOWIĄZAŃ POWSTAŁYCH W WYNIKU ZASTOSOWANIA ART. 90 UST. 1 KONSTYTUCJI RP}

Druga istotna kwestia, która należy wziąć pod uwagę, jest to, że art. 90 ust. 1 wymaga, by przekazanie kompetencji nastapiło na podstawie umowy międzynarodowej. W przypadku akcesji do UE, „warunki przyjęcia i wynikające z tego przyjęcia dostosowania w Traktatach stanowiaccych podstawę Unii sa przedmiotem umowy między państwami członkowskimi a państwem ubiegającym się o członkostwo" (art. 49 Traktatu o Unii Europejskiej5; podobnie było w chwili akcesji Polski do UE).

Potrzeba uwzględniania wspólnych wartości w funkcjonowaniu Unii została zaakcentowana w grudniu 2001 r. w Deklaracji Rady Europejskiej z Laeken na temat przyszłości UE. Uznano za stosowne wskazać, że: „Unia jest otwarta jedynie dla tych państw, które stoją na straży fundamentalnych wartości, takich jak wolne wybory, poszanowanie praw mniejszości i respektowanie zasad państwa prawnego. [...] Usankcjonowaniem istnienia Unii Europejskiej sa prezentowane przez nią demokratyczne wartości, cele, do jakich dąży, oraz uprawnienia i instrumenty, jakimi dysponuje" ${ }^{\text {. }}$.

Komentując art. 6 ust. 1 przedlizbońskiego Traktatu o Unii Europejskiej, omawiającego zasady, na których opierała się Unia (wolności, demokracji, poszanowania praw człowieka i podstawowych wolności oraz państwa prawnego), Cezary Mik zauważył, że postanowienie to pełniło dwojaką rolę. Z jednej strony zostały tutaj wymienione podstawowe wartości, które stanowiły fundament aksjologiczny Unii (tzw. tożsamość europejska), a jednocześnie były wartościami wspólnymi, uznawanymi za spoiwo państw członkowskich?

Traktat o przystapieniu w art. 1 przewidywał, że Polska (oraz inne państwa równocześnie przystępujące) staje się członkiem UE i oraz stroną Trak-

\footnotetext{
${ }^{4}$ Por. Zmiany w Konstytucji RP dotyczace członkostwa Polski w Unii Europejskiej. Dokumenty z prac zespołu naukowego powołanego przez Marszatka Sejmu, Warszawa 2010.

${ }^{5}$ Dz. Urz. UE 2012 C 326/13.

${ }^{6}$ Spotkanie Rady Europejskiej w Laeken 14-15 grudnia 2001 r. Wnioski prezydencji, <http:// oide.sejm.gov.pl/oide/images/files/dokumenty/konkluzje/laeken200112.pdf>.

7 Por. C. Mik, W. Czapliński, Traktat o Unii Europejskiej. Komentarz, Warszawa 2005, s. 69.
} 
tatów stanowiących podstawę Unii. Artykuł 90 został także wykorzystany w celu ratyfikacji Traktatu z Lizbony.

Obowiązujacy Traktat o Unii Europejskiej (TUE) zawiera w preambule wskazanie, że jego sygnatariusze byli inspirowani „kulturowym, religijnym i humanistycznym dziedzictwem Europy, z którego wynikaja powszechne wartości, stanowiące nienaruszalne i niezbywalne prawa człowieka, jak również wolność, demokracja, równość oraz państwo prawne”. Potwierdzono też „przywiązanie do zasad wolności, demokracji, poszanowania praw człowieka i podstawowych wolności oraz państwa prawnego".

Kluczowe znaczenie ma oczywiście art. 2 TUE, zgodnie z którym: „Unia opiera się na wartościach poszanowania godności osoby ludzkiej, wolności, demokracji, równości, państwa prawnego, jak również poszanowania praw człowieka, w tym praw osób należących do mniejszości. Wartości te są wspólne Państwom Członkowskim w społeczeństwie opartym na pluralizmie, niedyskryminacji, tolerancji, sprawiedliwości, solidarności oraz na równości kobiet i mężczyzn”.

Także Karta praw podstawowych UE, mająca taką samą moc prawną jak Traktaty unijne, zawiera w preambule wskazanie, że Unia opiera się na zasadach demokracji (akapit 2), a w części artykułowanej Karty zamieszczono katalog wolności wypełniajacych niewątpliwie pojęcie standardu demokratycznego (art. 6 - prawo do wolności bezpieczeństwa osobistego, art. 7 - poszanowanie życia prywatnego i rodzinnego, art. 8 - ochrona danych osobowych, art. 10 - wolność myśli sumienia i religii, art. 11 - wolność wypowiedzi i informacji, art. 12 - wolność zgromadzania się i stowarzyszania się).

\section{OBOWIĄZEK RESPEKTOWANIA PRZEZ RP WARTOŚCI WSPÓLNYCH PAŃSTWOM CZLONKOWSKIM UNII EUROPEJSKIEJ}

Należy się zastanowić, czy polskie rozwiązania konstytucyjne i powstała na ich tle praktyka pozwalają wypełniać wynikajacy z członkostwa w UE obowiązek respektowania wspólnych dla państw członkowskich wartości demokratycznych ${ }^{8}$.

Jeżeli współcześnie uważamy demokrację za wyróżnik cywilizacji Zacho$\mathrm{du}^{9}$, to powinniśmy mieć na uwadze jej rozumienie liberalno-demokratyczne, a więc takie, które zakłada istnienie konstytucyjnych mechanizmów kontrolowania władzy, niezawisłość sądów i wymiaru sprawiedliwości ${ }^{10}$, przestrzeganie praworządności, poszanowanie praw człowieka, w tym praw mniejszości ${ }^{11}$. W tym znaczeniu niezbędny w ustroju demokratycznym udział obywateli

${ }^{8}$ Por. szerzej K. Wojtowicz, Standardy demokratyczne Unii Europejskiej a Konstytucja RP - doświadczenia praktyki ustrojowej, w: J. Jaskiernia, K. Spryszak (red.), Dwadzieścia lat obowiqzywania Konstytucji RP. Polska myśl konstytucyjna a międzynarodowe standardy demokratyczne, Toruń 2017.

9 Por. C. Mik, W. Czapliński, op. cit., s. 72.

${ }_{10}$ Por. G. Sartori, Teoria demokracji, Warszawa 1994, s. 48-481.

11 Por. A. Rosas, L. Armati, EU Constitutional Law. An Introduction, 2nd edn., Hart Publishing, Oxford 2012, s. 128. 
w tworzeniu prawa, czy szerzej - w głosowaniu, można uznać za poprawna i skuteczną drogę sprawowania władzy politycznej, tylko wtedy, gdy odbywa się swobodnie, co oznacza, że jednostka oddająca swój głos do urny cieszy się wolnością sumienia, prasy, zgromadzeń i stowarzyszania się, czyli korzysta ze wszystkich swobód stanowiących istotę państwa liberalnego ${ }^{12}$.

Państwo demokratyczne to nie tylko państwo, w którym sprawnie działaja wszystkie jego organy, a prawo jest przestrzegane zarówno przez nie, jak i przez obywateli. Jest to niewątpliwie państwo praworządne, którego cecha jest zasada podziału władz. Żadna z władz w demokratycznym państwie prawnym ani żadna $\mathrm{z}$ instytucji w nim istniejacych nie może traktować państwa jako narzędzia do osiagania celów, ale jako miarę własnego postępowania. Demokratyczne państwo prawne „to państwo, w którym istnieje autonomiczny wobec niego system prawa, oparty na konstytucji, stanowiony w demokratycznym procesie, zaopatrzony w gwarancję przestrzegania i stosowania prawa, którego normy charakteryzują się tożsamością lub daleko idącą zbieżnością z systemem wartości powszechnie akceptowanym"13.

\section{KONSEKWENCJE NIEPRZESTRZEGANIA WSPÓLNYCH WARTOŚCI PRZEZ PAŃSTWO CZLONKOWSKIE W ŚWIETLE TRAKTATÓW UNIJNYCH}

Wymienienie w art. 2 TUE wspólnych państwom członkowskim wartości, na których opiera się Unia, nie ma charakteru niedajacej się wyegzekwować deklaracji. Wprost przeciwnie, do przestrzegania tych wartości zobowiązana jest nie tylko sama Unia i jej instytucje, ale bez wątpienia także państwa członkowskie. Świadczy o tym przede wszystkim treść dwóch przepisów traktatowych.

Pierwszy dotyczy przedakcesyjnych warunków, które musi spełnić państwo aspirujace do członkostwa w Unii Europejskiej. Zgodnie z art. 49 TUE: „Każde państwo europejskie, które szanuje wartości, o których mowa w artykule 2, i zobowiąuje się je wspierać, może złożyć wniosek o członkostwo w Unii [...]. Brane są pod uwagę kryteria kalifikacji uzgodnione przez Radę Europejska”".

Przypomnijmy w związku z tym, że już w 1961 r. Parlament Europejski podkreślił w sprawozdaniu dotyczącym przyszłych akcesji, że od państw kandydujacych powinno wymagać się poszanowania demokratycznych praktyk ${ }^{14}$. W 1997 r. Rada Europejska doprecyzowała, jakie treści powinny składać się na demokratyczny standard w państwach kandydujących. Są to: władza oparta

12 Por. N. Bobbio, Liberalizm i demokracja, Kraków 1998, s. 29.

13 J. Sobczak, Art. 11, w: A. Wróbel (red.), Karta praw podstawowych Unii Europejskiej. Komentarz, Warszawa 2013, s. 456-457.

${ }^{14}$ Por. Report on the Political and Institutional Aspects of Accession to or Association with the Community, 19 December 1961, za: N. Ghazaryan, The European Neighborhood Policy and the Democratic Values of the EU. A Legal Analysis, Oxford-Portland, Oregon, 2014, s. 118. 
na zasadzie przedstawicielstwa, odpowiedzialna egzekutywa, działanie władz publicznych w sposób zgodny z konstytucją i ustawami, podział władz, wolne i rzetelnie zorganizowane wybory w rozsąnych przedziałach czasu ${ }^{15}$. To, czy warunki sa spełnione, oceniane jest w trakcie specjalnej procedury, w ramach której Rada stanowi jednomyślnie, po zasięgnięciu opinii Komisji Europejskiej oraz po otrzymaniu zgody Parlamentu Europejskiego. Jest to zatem ocena polityczna i nie jest objęta jurysdykcją Trybunału Sprawiedliwości Unii Europejskiej ${ }^{16}$.

Polska została członkiem Unii Europejskiej 1 maja 2004 r., a zatem spełniała wymogi obejmujące m.in. przestrzeganie demokracji. Nie tylko dlatego, że Konstytucja RP w art. 2 stanowi, że: „Rzeczpospolita Polska jest demokratycznym państwem prawnym [...]”. Przede wszystkim dlatego, że polska praktyka konstytucyjna, wyrażona zwłaszcza w dotychczasowym orzecznictwie TK, nadała pojęciu demokracji treść spójną z elementami składającymi się na unijny standard demokratyczny. Trybunał uznał zasadę przedstawicielstwa za podstawę państwa demokratycznego, podkreślając przy tym, że w tego rodzaju państwie instytucje i procedury demokratyczne powinny być tak ukształtowane, by respektować wymogi państwa prawnego, które z kolei musi spełniać określone cechy materialne. Należy do nich podział władzy, wolności polityczne jednostki, pluralizm polityczny, ochrona mniejszości. Szczególny nacisk TK położył na poszanowanie zasady podziału władzy. Uznał mianowicie, że w stosunkach między władzą ustawodawczą a wykonawczą możliwe sa różne formy wzajemnych oddziaływań i współpracy, dopuszcza się również istnienie obszaru, w którym kompetencje należące do obu władz „przecinają się” lub „nakładaja”. Natomiast relacje między władzą sądowniczą a pozostałymi muszą opierać się na zasadzie „separacji”. Koniecznym elementem zasady podziału władzy są niezależność sądów i niezawisłość sędziów ${ }^{17}$.

Spełnienie kryteriów akcesyjnych nie oznacza, że po uzyskaniu członkostwa państwo będzie w dalszym ciagu szanowało wspólne wartości. Gdyby je naruszyło, możliwe jest wdrożenie procedury przewidzianej w art. 7 TUE. Postanowiono w nim m.in., że na uzasadniony wniosek jednej trzeciej państw członkowskich, Parlamentu Europejskiego lub Komisji Europejskiej Rada, stanowiąc większością czterech piątych swych członków po uzyskaniu zgody Parlamentu Europejskiego, może stwierdzić istnienie wyraźnego ryzyka poważnego naruszenia przez państwo członkowskie wartości, o których mowa w art. 2 TUE. Rada Europejska, stanowiąc jednomyślnie na wniosek jednej trzeciej państw członkowskich lub Komisji Europejskiej i po uzyskaniu zgody Parlamentu Europejskiego, może stwierdzić, po wezwaniu państwa członkowskiego do przedstawienia swoich uwag, poważne i stałe naruszenie przez to

15 Por. Council Conclusions of 29 April 1997 on the application of conditionality with a view to developing a coherent EU strategy for its relations with the countries in the region, za: ibidem, s. 119

16 Zwraca na to uwage C. Kaddous, The European Union's common values and national identities: convergence or contradictions, w: The EU between 'an Ever Closer Union' and Inalienable Policy Domains of Member States, Baden-Baden 2014, s. 85.

17 Por. P. Tuleja, Artykut 2, w: Konstytucja RP, t. 1: Komentarz art. 1-86, Warszawa 2016, s. 237-240 oraz omówione tam orzecznictwo TK. 
państwo członkowskie wartości, o których mowa w art. 2. Po dokonaniu tego stwierdzenia Rada, stanowiąc większością kwalifikowana, może zdecydować o zawieszeniu niektórych praw wynikających ze stosowania Traktatów dla tego państwa członkowskiego, łącznie z prawem do głosowania przedstawiciela rządu tego państwa członkowskiego w Radzie.

Postępowanie ma, podobne jak w przypadku art. 49 TUE, charakter polityczny z tym, że stosownie do art. 269 Traktatu o funkcjonowaniu Unii Europejskiej (TFUE) Trybunał Sprawiedliwości UE jest właściwy do orzekania w sprawie legalności aktu przyjętego przez Radę Europejską lub Radę na podstawie art. 7, ale wyłącznie na wniosek państwa członkowskiego, którego dotyczy postępowanie, oraz wyłącznie w odniesieniu do przestrzegania postanowień czysto proceduralnych przewidzianych $\mathrm{w}$ tym artykule.

Komisja Europejska w Komunikacie z 11 marca 2014 r. „Nowe ramy UE na rzecz umocnienia praworządności” podkreśliła, przywołując m.in. orzecznictwo Trybunału Sprawiedliwości UE oraz Europejskiego Trybunału Praw Człowieka, że „poszanowanie praworządności jest nierozerwalnie związane z poszanowaniem zasad demokracji i praw podstawowych: nie może być demokracji i poszanowania praw podstawowych bez poszanowania praworządności i odwrotnie. Prawa podstawowe sa skuteczne tylko wtedy, gdy moga być dochodzone na drodze sądowej. Demokracja jest chroniona, jeśli zasadnicza rola sądownictwa, w tym trybunałów konstytucyjnych, może zapewnić wolność wypowiedzi, wolność zgromadzeń oraz poszanowanie zasad regulujących proces polityczny i wyborczy"18.

Z kolei 25 października 2016 r. Parlament Europejski przyją na podstawie art. 295 TFUE rezolucję, w sprawie utworzenia unijnego mechanizmu dotyczacego demokracji, praworządności i praw podstawowych. Zawiera ona wniosek do Komisji o przedłożenie do września 2017 r. projektu Paktu UE na rzecz demokracji, praworządności i praw podstawowych. „Pakt ten, w formie porozumienia międzyinstytucjonalnego określającego współpracę instytucji Unii i państw członkowskich w ramach art. 7 TUE, ma dotyczyć zdefiniowania, opracowania, monitorowania i egzekwowania wartości i zasad wymienionych $\mathrm{w}$ art. 2 TUE (element prewencyjny i naprawczy art. 7 TUE). Ma on mieć zastosowanie do wszystkich państw członkowskich, jak również do trzech głównych instytucji UE, oraz połączyć w jeden unijny instrument istniejące komisyjne ramy dotyczące praworządności i dialog Rady dotyczący praworządności" 19 .

Obserwujemy zatem podejmowanie przez instytucje Unii wysiłków, mających na celu zapewnienie wypełniania przez państwa członkowskie swoich zobowiązań traktatowych dotyczących przestrzegania wartości, na których Unia się opiera.

${ }^{18}$ Komunikat Komisji do Parlamentu Europejskiego $i$ Rady, Strasburg, 11 marca 2014 r. COM(2014)158 final, s. 4-5.

19 Mechanizmy na rzecz przestrzegania praworzqdności $w$ Unii Europejskiej, wg stanu na 22 lutego 2017, Ośrodek Informacji i Dokumentacji Europejskie, Biblioteka Sejmowa, materiały OIDE, s. 4. 


\title{
$* * *$
}

Akcesja do UE dokonana na podstawie art. 90 ust. 1 Konstytucji RP była w sferze wartości zgodna z celem tego przepisu i spełniała warunki jego zastosowania. Także później w okresie członkostwa w UE polska praktyka ustrojowa nie odbiegała od unijnych standardów aksjologicznych. Sposób rozumienia demokratycznego państwa prawnego, o którym mowa w art. 2 Konstytucji RP, był bowiem spójny z treścią wartości wspólnych państwom członkowskim, stanowiących zgodnie z art. 2 TUE ustrojową podstawę Unii. Istotą systemu owych wspólnych wartości jest to, by realizowanie przez organy władzy publicznej woli obywateli wyrażonej w wolnych wyborach następowało z poszanowaniem zasad państwa prawnego, na które składają się przede wszystkim: podział władzy, ze szczególnym uwzględnieniem niezależności sądów i niezawisłości sędziów, pluralizm polityczny, ochrona praw jednostki, respektowanie praw mniejszości.

Nieprzestrzeganie wartości, o których mowa w art. 2 Konstytucji RP oraz w art. 2 TUE, podważyłoby cel i treść art. 90 ust. 1 Konstytucji, a w świetle wiążącego RP prawa unijnego mogłoby ją narazić na objęcie mechanizmem kontroli przewidzianym w art. 7 TUE.

prof. dr hab. Krzysztof Wójtowicz

Uniwersytet Wroctawski

kwojtow@prawo.uni.wroc.pl

\section{THE COMMUNITY OF THE EUROPEAN UNION VALUES FROM THE PERSPECTIVE OF ARTICLE 90(1) OF THE CONSTITUTION OF THE REPUBLIC OF POLAND}

\author{
Sum mary
}

In the field of values, the accession to the European Union carried out pursuant to Article 90(1) of the Constitution of the Republic of Poland was in line with the purpose of this article and met the conditions for its application. Also later, already during membership in the European Union, Polish political practice did not differ from EU axiological standards. The understanding of a democratic state governed by the rule of law as referred to in Article 2 of the Constitution was consistent with the content of values common to the Member States, which, in accordance with Article 2 of the TEU, constituted the political foundation of the Union. The essence of the system of these common values is that the fulfilment by public authorities of the citizens' will expressed in free elections is carried out with respect for the principles of the rule of law. These principles include mainly: the separation of powers, with particular regard to the independence of courts and the independence of judges, political pluralism, protection of individual rights and respect for minority rights. Failure to observe the values referred to in Article 2 of the Constitution and Article 2 of the TEU would undermine the purpose and content of Article 90(1) of the Constitution. According to the Constitution, and in the light of EU law binding for Poland, it could expose Poland to the control mechanism provided for in Article 7 TEU. 